\title{
PARTISIPASI POLITIK PENYANDANG DISABILITAS PADA PEMILIHAN UMUM KEPALA DAERAH (PILKADA) KOTA PAYAKUMBUH TAHUN 2017
}

\author{
Andre M. Fikri \\ Jurusan Ilmu Politik, Fakultas Ilmu Sosial dan Ilmu Politik, Universitas Andalas \\ Email: andremuhammadfikri030@gmail.com
}

\begin{abstract}
Abstrak
Partisipasi politik memilih dalam Pemilihan umum kepala daerah ini diatur dalam UndangUndang No.10 Tahun 2016 Tentang Pilkada. Penyandang Disabilitas merupakan orang berkebutuhan khusus dalam menjalani kesehariannya. Kota Payakumbuh merupakan Kota yang melaksanakan Pilkada serentak Tahun 2017 pasca ditetapkannya Undang-Undang yang baru tentang Pemilukada (Undang-Undang No.10 tahun 2016) dan juga lahirnya Undang-Undang No.8 Tentang Disabilitas. Tujuan dari penelitian ini adalah untuk mengetahui penyebab rendahnya Partisipasi Penyandang Disabilitas pada Pilkada di Kota Payakumbuh. Metode penelitian Kualitatif Deskriptif. Teknik pengumpulan data wawancara dan dokumemntasi. Pemilihan Informan adalah purposive sampling. Sementara teknik keabsahan adalah triangulasi. Dari hasil penelitian yang ditemukan bahwa yang menyebabkan rendanya partisipasi disabilitas pada Pilkada Kota Payakumbuh berasal dari dua faktor. Pertama faktor internal yaitu para disabilitas dan eksternal yaitu KPUD Kota Payakumbuh, PPDI dan Partai Politik di Kota Payakumbuh. Temuan penelitian: penyebab utama rendahnya angka partisipasi penyandang disabilitas berasal dari faktor eksternal yaitu KPUD Kota Payakumbuh. Hal ini dikarenakan oleh tidak tepatnya sasaran sosialisasi yang diberikan dan kurangnya perhatian penyelenggara terhadap disabilitas. Sementara temuan dari faktor internal didapati bahwasannya penyandang disabilitas cukup memiliki kesadaran akan demokrasi dan hak pilih mereka pada Pilkada Kota Payakumbuh.
\end{abstract}

Kata kunci : Pilkada; Faktor Internal ; Faktor Eksternal ; Penyandang Disabilitas

\begin{abstract}
Political participation in the election of the regional head general governs in Law No.10 of 2016 concerning Pilkada. Persons with disabilities are people with special needs in their daily activities. Payakumbuh City is a city that holds simultaneous local elections in 2017 after the promulgation of a new Law on Pemilukada (Law No.10 of 2016) and also the birth of Law No. 8 About Disability. The purpose of this study was to determine the cause of the low Participation of Persons with Disabilities in the Local Election in Payakumbuh City. Descriptive Qualitative Research Methods. Data collection techniques used were interviews and documentation. The selection of informants is purposive sampling. While the validity technique is triangulation. From the results of the study found that causing disability in the Payakumbuh Election benefited from two factors. First internal factors are the disabilities and external namely the Election Commission Payakumbuh City, PPDI and Political Parties in the City of Payakumbuh. Research findings: The main cause of the low disability participation rate comes from external factors, namely the Election Commission of Payakumbuh City. This is caused by not opposing the socialization target given and not paying attention to disability. While findings from internal factors, it is found that disability has sufficient awareness of democracy and their suffrage in the Payakumbuh Regional Election.
\end{abstract}

Keywords: Local Election ; Internal Factors ; External Factors ; Persons with Disabilities 


\section{PENDAHULUAN}

Partisipasi politik memilih akan selalu berkaitan erat dengan Pemilihan Umum, khususnya dalam pemilihan kepala daerah atau disingkat Pilkada.Pilkada sendiri sekarang ini sudah memasuki babak barunya setelah proses panjang. Pilkada mengalami berbagai bentuk perubahan baik dalam undang - undang dan aturan pemilu lainnya. Pada tahun 2015 untuk pertama kalinya penyelenggaraan Pemiluyang dilakukan olehKPU melakukan Pemilihan kepala daerah langsung secara serentak, meski tidak secara keseluruhan dilakukan di kota dan kabupaten seluruh Indonesia, namun Pilkada ini menurut KPU akan menjadi sebuah cikal-bakal Pilkada serentakdi Indonesia yang akandi proyeksikan akan mengirit biaya politik di Indonesia, sebab selama ini dibilang cost politic di Indonesia cukup mahal. Terobosan baru ini adalah kesepakatan terbaru yang tercapai antara Pemerintah dan DPR RI dalam pembahasan perubahan UndangUndang nomor 1 tahun 2015 tentang peraturan penetapan pemerintah atas UndangUndang No 1 tahun 2014 tentang pemilihan Gubernur, Bupati dan Walikota . ${ }^{1}$ Setelah itu pada tahun 2016 Presiden republik Indonesia bersama DPR RI kembali menyepakati undang-undang NO.10 tahun $2016 .{ }^{2}$ Perubahan peraturan tersebut membuat Pilkada serentak diharapakan akan tercapai pelaksanaanya secara bersama untuk seluruh provinisi, kabupaten dan kota di tahun 2017.

Sebagai sebuah Negara demokrasi yang semakin berkembang dan maju, Dalam sebuah Pemilihan Umum (PEMILU) Partisipasi Politik merupakan hal penting yang harus dimaknai masyarakat sebagai sebuah kewajiban mereka sebagai warga Negara di Negara demokrasi, meski secara luas partisipasi politik tidak hanya persoalan ikut memilih pada Pemilu. Namun lebih dari itu, Partisipasi Politik lebih luasnya adalah bagian dari sebuah proses berdemokrasi negara yang menganut asas demokrasi. Disebuah perhelatan Pilkada, Partisipasi Politik seseorang yang identik penggunaan hak memilih. Menurut Luthfi Munzir: Mereka yang menggunakan hak pilihnya dalam sebuah perhelatan Pemilihan Umum secara langsung adalah bukti dari seseorang tersebut ikut berpatisipasi politik dalam sebuah perhelatan demokrasi khususnya. Pemilihan Umum. Penggunaan hak pilih pada Pemilu ini sangatlah penting, karena Menggunakan hak pilih dalam Pemilu dan Pilkada tidak saja dipahami sebagai seremonial lima tahunan pesta demokrasi secara nasional dan lokal, tetapi menggunakan hak pilih harus dimaknai sebagai upaya perbaikan kepemimpinan secara nasional dan lokal agar tepat memilih calon pemimpin, artinya akan memberikan perbaikan bagi negara atau daerah lima tahun yang akan dating. ${ }^{3}$

\footnotetext{
${ }^{1}$ Budi setiawanto. (2015, Februari, 17) tujuh gelombang Pilkada serentak 2015- 2027. Antara News. https://www.antaranews.com/berita/480618/tujuh-gelombang-pilkada-serentak-2015-hingga-2027. (Diakses pada 20 Februari 2017)

${ }^{2}$ Mahkamah Konstitusi, Tentang Perubahan Undang-undang No 1 tahun 2015 menjadi UU no!0 tahun2016.http://www.mahkamahkonstitusi.go.id/public/content/jdih/UU_Nomor_10_Tahun_2016.pdf. (Diakses pada 20 Februari 2018)

3 M. Luthfi Munzir, Rumah Pintar Pemilu, 1(1). http://kpud-medankota.go.id/rumah-pintarpemilu/?upm_export=pdf (Diakses Pada 1 Maret 2018)
} 
Mengenai partisipasi politik khususnya partisipasi memilih dalam Pilkada. Disabilitas merupakan salah satu elemen masyarakat yang selama ini dianggap termarginalkan, khususnya di negara - negara berkembang seperti Indonesia.hal ini terlihatberdasarkan temuan The asia Foundation, 35\% lebih para penyandang disabilitas tidak mempunyai akses ke Pemilu atau tidak paham akan Pemilu, artinya masih ada terdapat $35 \%$ lebih parapenyandang disabilitas di Indonesia yang memiliki hak suara namun tidak mampu menggunakan hak suaranya di Pemilu. ${ }^{4}$ Artinya masih ada kurangnya perhatian dari pemerintahan yang ada dalam mengatur tentang hak-hak disabilitas. Hal tersebut juga dapat dikuatkan dan tergambar dari kurangnya fasilitas fasilitas penunjang dalam setiap Pemilihan Umum yang membantu disabilitas dalam melakukan hak pilihnya, seperti surat suara braile untuk tuna netra, atau kursi roda bagi tuna daksa dan fasilitas lainnya tergantung kebutuhannya. Sementara sebagai masyarakat di suatu negara demokrasi, mereka secara hak adalah warga negara yang tercatat sebagai penduduk yang memiliki hak politik khususnya hak memilih pada Pemilu Bagaimanapun negara seharusnya berkewajiban untuk memenuhi kebutuhan mereka, meskipun jumlah mereka para penyandang disabilitas tidak terlalu banyak, namun partisipasi mereka dalam setiap pemilihan harus dan tetap dijaga tingkatannya. Sementara itu partisipasi mereka para penyandang disabilitas juga menjadi acuan sebuah suskesnya demokrasi suatu Negara, seperti Indonesia negara berkembang yang dewasa ini semakin intens dan serius untuk memprioritaskan hak penyandang disabilitas termasuk kebutuhan mereka dalam menggunakan hak pilih pada Pemilu. Dengan keadaan ini tentu sudah seharusnya penyelenggara seperti KPU dan KPUD menjdi ujung tombak suksesi partisipasi masyarakat penyandang disabilitas.

Selanjutnya, dengan adanya rasa tanggung jawab Komisi Pemilihan Umum (KPU)untuk menunjang angka partisipasi mereka, Dalam hal ini KPU berusaha mendorong Pemilu yang iknlusif dan dan melayani terhadap disabilitas, hal ini karena didukung oleh aturan yang berlaku. Salah satunya, dengan diterbitkan Undang-Undang No.8 Tahun 2016 tentang Penyandang Disabilitas, pada Bab 1 Ketentuan Umum, Pasal 1. ${ }^{5}$ Dalam Undang-Undang tersebut menjelaskan bahwa Penyandang Disabilitas adalah setiap orang yang mengalami keterbatasan fisik, intelektual, mental, dan/atau sensorik dalam jangka waktu lama yang dalam berinteraksi dengan lingkungan dapat mengalami hambatan dan kesulitan untuk berpartisipasi secara penuh dan efektif dengan warga negara lainnya berdasarkan kesamaan hak.

Sebelumnya pada pasal 43 ayat 1 Undang - Undang Nomor 39 Tahun 1999 Tentang Hak Asasi Manusia (HAM), para penyandang disabilitas sebagai bagian dari warga negara Indonesia berhak terlibat aktif dalam kehidupan politik. Hal ini

\footnotetext{
${ }^{4}$ Merly Mario, 2015. Aksesbilitas Pemilu 2014 Dan Implikasinya Terhadap Ketahanan Politik (Studi Tentang Persepsi Mahasiswa Penyandang Disabilitas di Pusat layanan difabel UIN Sunan Kali Jaga Yogyakarta), Jurnal Ketahanan Nasional, 21, hal 61-77.

${ }^{5}$ Republik, Indonesia ,Undang-undang No. 8 Tentang Penyandang Disabilitas Tahun 2016, http://www.kemendagri.go.id/media/documents/2016/05/11/u/u/uu_nomor_8_tahun_2016.pdf (diakses pada 1 Maret 2018)
} 
menerangkan bahwa setiap warga negara berhak mendapatkan kesempatan yang sama dalam kehidupan bernegara termasuk dalam berdemokrasi, seperti hak mereka untuk dipilih maupun memilih. Dengan hadirnya Undang- Undang disabilitas ini sekaligus semakin menejelaskan bahwa negara dalam hal ini sudah seharusnya wajib bersama KPU sebagai penyelenggara Pilkada untuk memfasilitasi mereka penyandang disabilitas disetarakan kesamaan haknya, karena tidak hanya undang-undang No. 8 Tentang penyandang disabilitas saja yang mengatur tentang kesamaan hak ini, sebelumnya kesamaan Hak antara disabilitas yang memang berbeda degan hak masyarakat pada umumya ini juga dibicarakan dalam konverensi konveksi hak-hak penyandang disabilitas atau Convetion On The Rights Of Persons With Disabilities(CRPD). ${ }^{6}$ Disana para Negara - negara yang terlibat membahas tentang penguatan penyandang disabilitas dalam kesamaan haknya dalam kehidupan bernegara dan demokrasi. Konvensi ini disepakati pada tanggal 13 Desember 2006 oleh Majelis Umum Perserikatan BangsaBangsa dengan Resolusi 61/106 dan terbuka untuk ditandatangani oleh Negara-negara anggota PBB pada tanggal 30 Maret 2007.Barulah empat tahun kemudian Indonesia telah meratifikasi konvensi tersebut melalui Undang - undang No 19 Tahun 2011 Tentang Pengesahan Konvensi Hak-hak Penyandang Disabilitas pada tanggal 18 Oktober 2011 yang menjamin hak penyandang disabukitas dalam Pemilu, sekaligus menjadikan rujukan awal lahirnya Undang-Undang No 8 tahun 2016 tentang penyandang Disabilitas.

Kehadiran Undang-undang inilah yang menjadikan KPU bersamaan ini dengan KPUD berkewajiban untuk menyetarakan kesamaan hak disabilitas dalam Pilkada, artinya ada kepedulian terhadap mereka kaum Disabilitas agar dapat menjamin kesamaan hak mereka pada setiap perhelatam Pemilihan Umum. Maka dari itu, salah satu bukti bahwa KPU dan KPUD berkomtimen untuk menjamin kesetaraan tersebut yaitu dengan melakukan sosialisasi politik kepada mereka kaum disabilitas pada setiap perhelatan Pemilihan Umum, ini artinya KPU dan KPUD memiliki kepedulian terhadap mereka sebagai pemilih yang sama dengan pemilih lainnya, baik dalam sebuah Pemililhan Legislatif, Pemilihan Presiden atau Pemilihan Daerah yangada dimasing masing tempat pemilih disabilitas tersebut.

Namun meski KPU dan KPUD telah beranggapan telah berupaya maksimal dalam upaya peningkatan partisipasi para penyandang disabilitas, di beberapa daerah partisipasi mereka penyandang disabilitas masih saja rendah.Seperti di Sumatera Baratpada Pilkada Serentak 2017 yang dilaksanakan di dua daerah Kota Payakumbuh dan Kab. Mentawai.Jika dibandingkan Pilkada serentak yang juga dilaksanakan di Kab. Mentawai, maka Kota Payakumbuh partisipasi penyandang disabilitasnya masih rendah dibandingkan dengan Kab. Mentawai dalam Pilkada serentak tahun 2017.Telah diaturnya Undang-Undang No. 8 tentang disabilitias yang menjadi acuan KPU untuk

\footnotetext{
${ }^{6}$ Kemenkumham, Konvensi Hak-Hak Penyandang Disablitas (Convetion On The rights Of Persons WithDisabilities, https://jabar.kemenkumham.go.id/attachments/article/1493/konvensi\%20hakhak\%20pe nyandang\%20disabilitas.PDF di akses pada 1 maret 2018
} 
bertanggung jawab memperhatikan para pemilih disabilitas dalam setiap pemilu, KPUD juga sudah bersikap baik dalam hal - hal upaya peningkatan partisipasi mereka.

Bentuk perhatiannya ini, KPU dan KPUD memiliki sikap bahwasanya dalam hal menunjang partisipasi politik disabilitas adalah tugas dan kewajiban lembaga mereka sebagai penyelenggara, hal ini juga dapat dilihat dalam setiap Pilkada serentak yang sudah berlangsung sejak tahun 2015, dimana KPU sudah mulai mengkalifikasikan bentuk dan golongan penyandang disabilitas berdasarkan kebutuhanya. Ada 5 golongan disabilitas yang diklasifikasikan oleh KPU, diantaranya :

\section{Gambar 1 \\ Jenis - Jenis Disabilitas}

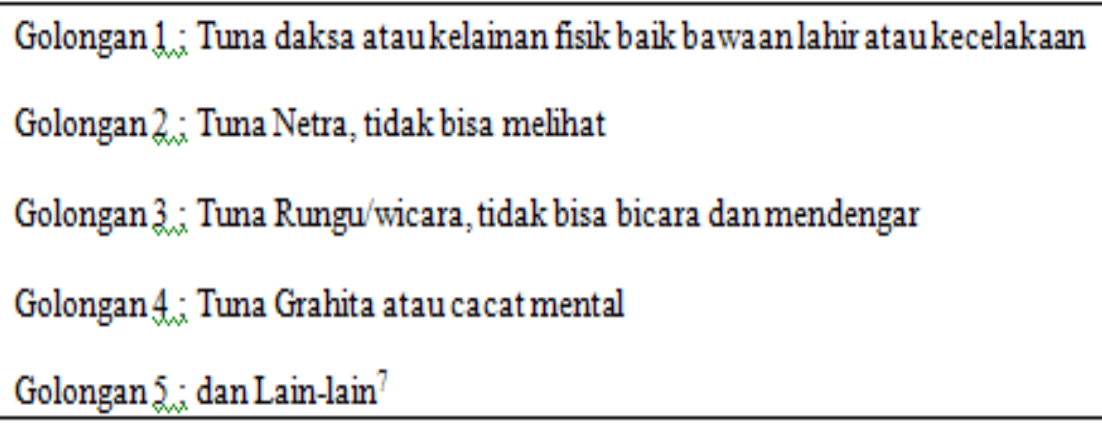

Sumber ; KPU Republik Indonesia

Adanya pendataan dengan mengklasifikasikan disabilitas dengan kebutuhanya ini adalah untuk upaya memfasilitasi mereka disabilitas dalam menggunakan hak pilih nanti, agar sesuai fasilitas yang diberikan dengan kebutuhan mereka penyandang disabilitas, sehingga diharapkan mereka nantinya tidak memiliki kendala ketika menjalankan hak pilihnya di TPS. sebagai contoh: Pemilih tuna netra membutuhkan surat suara khusus, Pemilih tuna daksa membutuhkan pendampingan seperti kursi roda, dan lainnya sesuai kekurangan fisik dan kebutuhannya. Sebelumnya, KPU belum pernah mengkalsifikasian data pemilih disabilitas pada setiap Pemilu baik Pilkda, Pileg ataupun Pilpres.

Meski sudah adanya pengklasifikasian golongan disabilitas, hal tersebut tidak berpengaruh cukup banyak terhadap angka partipasi disabilitas dalam Pilkada serentak yang dilakukan di Sumatera Barat didua daerah Kota Payakumbuh dan Kabupaten Mentawai. Bisa dilihat pada tabel dibawah, khsusus di Kota Payakumbuh.

\section{Gambar 2.}

Data Pengguna Hak Pilih Disabilitas pada Pilkada Serentak Sumatera Barat (Kota Payakumbuh dan Kabpaten Mentawai) 


\begin{tabular}{|c|c|c|c|}
\hline KotaKabupaten & DPT & $\begin{array}{c}\text { Pengguna Hak } \\
\text { Pilih }\end{array}$ & Persentase \\
\hline Kota Payakumbuh & 143 & 61 & $42 \%$ \\
\hline Kab.Kep.Mentawai & 29 & 22 & $75 \%$ \\
\hline
\end{tabular}

\section{Sumber ; KPU Republik Indonesia}

Dari tabel diatas terlihat bahwa angka partisipasi Penyandang Disabilitas masih rendah, terutama dalam Pilkada Kota Payakumbuh jika dibandingkan dengan Kab Mentawai. Sementara itu KPU RI pada Pilkada serentak tahun 2017 menargetkan angka partisipasi pada Pemilu berada di angka $70 \%$, maka dengan $42 \%$ angka partisipasi disabilitas, maka bisa digolongkan sebagai angka partisipasi yang rendah untuk bicara rendah dan tingginya sebuah patokan angka partisipasi pada pemilihan.kemudian tentang sosialisasi seputar Pilkada sudah dilaksanakan oleh pihak penyelenggara kepada para penyandang disabilitas di Kota Payakumbuh,seperti ditempa SLB YPPLB Kota Payakumbuh. Disana KPUD melakukan kunjungan sekaligus sosialisasi Pilkada kepada siswa dan siswi. Sementara itu jika kita bicara DPT (daftar pemilih tetap) mereka penyandang disabilitas Kota Payakumbuh sudah terdata dengan baik dari halaman website KPU, dapat dilihat pada tabel di bawah ;

\section{Gambar 3.}

Jumlah Pemilih tetap disabilitaspada Pilkada Kota Payakumbuh Tahun 2017

\begin{tabular}{|l|l|l|l|l|l|l|}
\hline $\begin{array}{l}\text { Daftar } \\
\text { Kecamatan }\end{array}$ & $\begin{array}{l}\text { DP } \\
\text { tuna } \\
\text { daksa }\end{array}$ & $\begin{array}{l}\text { DP } \\
\text { tuna } \\
\text { netra }\end{array}$ & $\begin{array}{l}\text { DP tuna } \\
\text { rungu }\end{array}$ & $\begin{array}{l}\text { DP tuna } \\
\text { grahita }\end{array}$ & $\begin{array}{l}\text { DP } \\
\text { disabilitas } \\
\text { lainnya }\end{array}$ & Jumlah\% \\
\hline Lamposi Tigo Nagari & 1 & 1 & 2 & 0 & 1 & $5(0,07)$ \\
\hline Payakumbuh Barat & 32 & 9 & 17 & 5 & 5 & $68(0,21)$ \\
\hline Payakumbuh Selatan & 4 & 1 & 5 & 0 & 0 & $10(0,14)$ \\
\hline Payakumbuh Timur & 6 & 9 & 18 & 8 & 9 & $50(0,29)$ \\
\hline Payakumbuh Utara & 9 & 6 & 8 & 11 & 0 & $34(0,17)$ \\
\hline Jumlah & 52 & 26 & 50 & 24 & 15 & $167(0,20)$ \\
\hline
\end{tabular}

Sumber :www.kpu.go.id, Diakses pada 19 februari 2018.

Dari tabel di atas terlihat bahwa pendataan yang dilakukan sudah cukup Baik dilakukan oleh pihak penyelenggara dalam hal ini KPUD Kota payakumbuh, dan jumlah mereka tercatat sebanyak 0,20\% dari DPT yang terdata jika dipersentasekan.

Dengan sudah adanya Daftar pemilih tetap (DPT) para disabilitas, namun perihal masalah masih rendahnya angka partisipasi para penyandang disabilitas tersebut. Saat ditemui, Menurut Yuzalmon Komisioner KPUD kota Payakumbuh bagian Sosialisasi) ${ }^{7}$. beliau menyatakan:

\footnotetext{
${ }^{7}$ Wawancara dengan Yuzalmon, Anggota KPU bagian sosialisasi, wawancara 19 Februari 2018.
} 
"bahwa pihak KPUD Kota Payakumbuh telah melakukan upaya maksimal untuk meningkatkan partisipasi para penyandang disabilitas, terutama hal yang kami lakukan adalah sosialisasi kepada sekolah luar biasa."

Namun hal lainditemui ketika melakukan wawancara kepada para penyandang disabilitas di SLB tempat KPUD Kota Payakumbuh melakukan sosialisasi seputar Pilkada. Menurut Merry (guru sekaligus penyandang tuna netra), menurutnya:

"KPUD Kota Payakumbuh memang sudah melakukan sosialisasi ke SLB disini, dan kami semua menghadiri, akan tetapi sosialisasi tersebut dilakukan kepada kami yang bukan merupakan penyandang disabilitas pemilik E Ktp Kota Payakumbuh, kami tidak mempunyai hak pilih dalam pilkada kota payakumbuh, sehingga kami hanya mendapatkan sosialisasi akan tetapi secara hak pilih kami tidak bisa ikut memilih, bahkan satupun siswa di SLB ini yang sudah memiliki E ktp semuanya adalah siswa yang tidak memiliki E ktp Payakumbuh"».

Adanya dua informasi yang saling melengkapi menjelaskan bahwa sejauh ini peran KPUD untuk mengupayakan partisipasi disabilitas meningkat sudah cukup baik, namun kesalahannya terdapat pada sasaran dan target yang diberikan sosialisasi. Selain itu pihak penyelenggara juga hanya melakukan satu kali sosialisasi sementara ada sebelas sekolah luar biasa (SLB) yang ada di kota Payakumbuh.

Seperti SLB khusus tuna rungu, disana siswa yang memilki E Ktp Kota Payakumbuh tidak mendapatkan sosialisasi tentang Pilkada dari KPUD Kota Payakumbuh, Menurut David (dibantu guru khusus tuna rungu sebagai penerjemaah) ${ }^{9}$ :

"Saya tidak pernah diajak sosialisasi oleh KPUD Kota payakumbuh untuk Pilkada, saya sudah memiliki E Ktp dan sudah menggunakan hak pilih saya sebagai warga negara, Bagi saya menggunakan hak pilih itu harus, meski tidak ada sosialisasi oleh KPUD kami sudah paham tentang pentingnya hak suara kami, karena sekolah kami sudah berinisiatif melakuakn pendidikan politik seputar pilakda tersebut".

Dari pendapat para penyandang disabilitas tuna rungu di atas, dapat tergambarkan bahwa sosialisasi mengenai Pilkada tidak dirasakan semua para penyandang disabilitas, masalahnnyaadalah apakah data yang ada pada KPUD tentang penyandang disabilitas terdaftar sebagai pemilih disabilitas tersebut yang berasal dari siswa - siswi di SLB yang ada di Kota payakumbuh. Karena ketidak tepatan sosialisasi akan berdampak pada hasil dari angka partisipasi.

Jadi penyebab rendahnya partisipasi politik memilih para penyandang disabilitas dalam pada Pilkada Kota Pakumbuh, adalah adanya dua permasalahan yang

\footnotetext{
${ }^{8}$ Wawancara dengan Mery, disabilitas penyandang tuna netra dan juga guru SLB YLBB Kota Payakumbuh

${ }^{9}$ Wawancara dengan Devid, disabilitas penyandang tuna rungu di SLB khusus tuna rungu Kota Payakumbuh
} 
menjadikan partisipasi penyandang disabilitas masih rendah, yaitu kemungkinan dari faktor individu disabilitasnya atau disebut juga sebagai faktor internal, dan faktor dari lingkungan, system atau penyelenggara Pilkada dalam hal ini KPUD disebut juga sebagai faktor eksternal. Jadi berdasarkan asumsi di atas, penelitian ini akan mencoba melihat lebih jauh permasalahan yang ada terhadap partisipasi penyandang disabilitas, maka yang menjadi pertanyaan peniliti penulis adalah; mengapa partisipasi politik penyandang disabilitas rendahpada Pemilihan Kepala Daerah Kota Payakumbuhn Tahun 2017 ?

\section{Teori dan Konsep}

Menurut freed J. Greeinstein dan Nelson W. Polsby kepribadian dan politik mampu menjelaskan dua hal yaitu, Pertama, tindakan yang ditampilkan seseorang merupakan dari dua hal utama yaitu karakteristik pribadi dan lingkungan tempat orang itu berada. Kedua, Semakin kabur dan tak berstruktur lingkungan, semakin besar karakteristik pribadi seseorang dalam mempengaruhi tindakannya. ${ }^{10}$ Dua hal di atas ini penting untuk menjelaskan bagaimana dua aktor antara individu masyarakat atau mikro politik dengan pengaruh-pengaruh dari psikologisnya yang diakibatkan oleh aktor sistem makro politik atau sistem politik yang ada dalam mempengaruhi individu masyarakat atau mikro politik.Menurut Watson mengatakan bahwa ada beberapa kendala (hambatan) yang dapat menghalangi terjadinya suatu perubahan antara lain kendala yang berasal dari kepribadian individu salah satunya adalah ketergantungan. Ketergantungan masyarakat terhadap pemerintah dalam pelaksanaan kegiatan pembangunan merupakan hambatan dalam mewujudkan partisipasi masyarakat secara aktif, karena rasa ketergantungan ini masyarakat tidak memiliki inisiatif untuk melaksanakan pembangunan. Maka dengan sederhananya ada dua hal inti yang menjadi persoalan disabilitas berdasarkan uraian di atas yaitu.

\section{Faktor Internal}

Faktor-faktor internal adalah berasal dari dalam kelompok masyarakat sendiri, yaitu individu-individu dan kesatuan kelompok didalamnya. Tingkah laku individu berhubungan erat atau ditentukan oleh ciri-ciri sosiologis seperti umur, jenis kelamin, pengetahuan, pekerjaan atau penghasilan. Secara teoritis, terdapat hubungan antara ciriciri individu dengan tingkat partisipasi, seperti usia, tingkat pendidikan, jenis pekerjaan, lamanya menjadi anggota masyarakat, besarnya pendapatan, keterlibatan dalam kegiatan pembangunan akan sangat berpengaruh pada partisipasi. Dalam faktor Internal ada dua hal yang memperngaruhi Partisipasi Politik disabilitas yang ada di bawah ini.

\section{Orientasi Politik}

Dalam penelitian ini peneliti menggunakan konsep kepribadian dan politik yang diperkenalkan oleh Fred J. Greenstein, menurutnya: Politik dipengaruhi Oleh kepribadian sehingga konsep kepribadian dan politik merupakan upaya untuk

\footnotetext{
${ }^{10}$ Fred J. Greeinstein dan Nelson W. Polsby, Handbook of Political science"micropolitical theory" vol III
} 
mempelajari fenomena atau sindrom yang dilakukan oleh individu dalam berpolitik hal ini dijelaskan dalam bukunya Personality and Politic ${ }^{11}$. Orientasi politik merupakan sikap umum dan komitmen individu, kelompok ataupun negara terhadap lingkungan eksternal, strategi dasar untuk mencapai tujuan aspirasi, serta mengatasi ancaman. Orientasi jarang terungkap dalam sebuah keputusan yang dibuat dalam usaha menyesuaikan tujuan, nilai, dan kepentingan terhadap kondisi dan lingkungan. Orientasi ini dibenarkan oleh cristoper Llyod yang mengatakan bahwa orientasi politik akan tampak dalam sebuah tindakan. ${ }^{12}$

Orientasi politik berkaitan dengan sikap politik yang dilakukan individu atau kelompok, dan menjadi landasan dalam berpolitik. Serta ini juga dipengaruhi oleh faktor-faktor ideologis yang dimilikinya. Orientasi politik dalam kegiatan bernegara adalah sebuah hal wajar untuk dimiliki dalam mencapai tujuan - tujuannya. Orientasi politik lahir karena adanya respons terhadap kondisi eksternal. Kondisi negara, masyarakat ataupun dunia internasional menjadi sangat penting untuk menciptakan sebuah orientasi politik, orientasi politik juga berkaitan erat dengan strategi politik atau mencapai sebuah tujuan, dan mengatasi ancaman yang terjadi. Dengan orientasi politik ini seseorang, sekelompok orang, organisasi maupun negara akan memiliki sebuah ideologi dan langkah yang nyata untuk mencapai tujuannya. Untuk melihat orientasi dapat diamati berdasarkan: Orientasi kognitif, orientasi ini bersumber pada segala macam pengetahuan serta kepercayaan yang ada pada politik, peranan serta kewajiban yang menyertainnya. Hal ini mencakup komponen input dan output.

\section{Motivasi Politik}

Faktor-faktor yang mempengaruhi motivasi dalam memilih menurut Sobirin Malian terbagi menjadi dua, yaitu intrinsik dan ekstrinsik: Pertama, motivasi intrinsik adalah motif-motif yang menjadi aktif atau berfungsinya dirangsang dari luar, karena dalam setiap individu sudah ada dorongan untuk melakukan sesuatu. Terdapat dua faktor pendorong seseorang menggunakan hal pilihnya pada pemilu yang berasal dari dalam diri, yaitu:Kesadaran Politik, dan Kepercayaan Terhadap Pemerintah. Kesadaran Politik yaitu kesadaran akan hak dan kewajiban sebagai warga negara. Tingkat kesadaran politik diartikan sebagai tanda bahwa warga masyarakat menaruh perhatian terhadap masalah kenegaraan dan atau pembangunan. Apakah mereka mengikuti atau menaruh perhatian pada urusan-urusan pemerintahan dan politik termasuk kampanye Pilkada.

Kesadaran politik seseorang ini terlihat dari pengetahuan terhadap perkembangan politik:

a. Perasaan yang membuat pemilih mengertidandengan sadar mengikuti perkembangan politik yang sedang berlangsung.

b. Minat terhadap politik:

\footnotetext{
${ }^{11}$ Loc.cit, Hal 17

${ }^{12}$ Christopher Llyod, Teori sosial dan Praktek politik, Rajawali, jakarta, 1986, hlm 13
} 
Perasaan dimana seseorang tertarik untuk turut serta dalam proses politik.

c. Perhatian terhadap politik:

Proses poltik yang sedang berlangsung menarik perhatian pemilih sehingga pemilih memiliki perhatian yang lebih terhadap proses politik.

Sementara kepercayaan terhadap pemerintah yaitu sikap dan kepercayaan orang tersebut terhadap pemerintah. Kepercayaan terhadap pemerintah dapat juga diartikan penilaian seseorang terhadap pemerintah apakah pemerintah dapat dipercaya dan dapat dipengaruhi. Kepercayaan ini terlihat dari keyakinan pada Pemerintah, keyakinan bahwa melalui kegiatan itu kepentingan mereka akan tersalur atau sekurangnya diperhatikan dan sedikit banyak dapat mempengaruhi tindakan yang berwenang yang diwujudkan dalan sebuah keputusan. Mau bekerjasama dengan pemerintah Masyarakat percaya bahwa kegiatan yang mereka lakukan mempunyai efek (political efficacy). Sehingga berdasarkan kepercayaan itu masyarakat mau bekerjasama dengan pemerintah untuk memajukan negara dan daerahnya.

\section{Faktor eksternal}

Faktor-faktor eksternal ini dapat dikatakan dipengaruhi oleh (stakeholder), yaitu dalam hal ini stakeholder mempunyai kepentingan dalam setiap program. Dalam hal ini seperti pemerintah daerah, pemerintah desa, tokoh masyarakat/adat dan konsultan/fasilitator. ${ }^{13}$ Selain itu pengaruh dari luar yang mempengaruhi seoarang disabilitas juga berasal dari motivasi ekstrinsik. Motivasi Ekstrinsik adalah Motivasi yang berasal dari motif-motif yang aktif dan berfungsinya karenaadanya perangsang dari luar, terdiri dari peer groupdan simbol pergerakan. Peer group adalah lingkungan sosial diluar individu dimana proses sosialisasi dan transformasi dapat berjalan. Faktor pendorong seseorang menggunakan hak pilihnya yang diakibatkan dari luar diri individu terbagi menjadi dua faktor, yaitu Identitas partai dan penampilan kandidat pilkada. $^{14}$

\section{Partisipasi Politik Penyandang Disabilitas Kota Payakumbuh}

Seseorang yang ingin atau tidaknya melakukan partisipasi politik terjadi karena adanya dua faktor, yaitu faktor internal dan eksternal. Faktor internal pada partisipasi penyandang disabiltias yang dimaksud adalah individu para penyandang disabilitas yang akan menggunakan hak pilihnya pada Pilkada Kota Payakumbuh tahun 2017. Disini ada lima macam jenis - jenis disabilitas yang diklasifikasikan oleh KPU, dan setiap jenis disabilitas memiliki ragam permasalahan terhadap keinginannya memilih atau tidaknya dalam berpatisipasi pada Pilkada Kota Payakumbuh.

\footnotetext{
${ }^{13}$ Soetomo, Masalah Sosial dan Pemecahanya, Pustaka belajar, Yogyakarta, 2008, hlm 214

${ }^{14}$ Sobirin Malian,Menakar Loyalitas dan Volatilitas Pemilih Pada Pemilu 2004, UNISIA, lampung, , 2016, hal 81.
} 


\section{METODE PENELITIAN}

Penelitian ini menggunakan metode kualitatif. Bogdan dan Taylor ${ }^{15}$ mengemukakan bahwa metodologi kualitatif merupakan prosedur penelitian yang menghasilkan data deskriptif berupa kata-kata tertulis maupun lisan dari orang-orang dan perilaku yang diamati. Penelitian ini menggunakan tipe penelitian deskriptif.

Menurut Sugiyono, penelitian deskriptif yaitu penelitian yang dilakukan untuk mengetahui nilai variabel mandiri, baik satu variabel atau lebih (independen) tanpa membuat perbandingan, atau menghubungkan dengan variabel yang lain ${ }^{16}$. Dengan pendekatan ini diharapkan temuan-temuan empiris dapat di deskripsi secara lebih rinci, jelas dan akurat, ${ }^{17}$ yaitu hal-hal yang berkaitan partisipasi politik penyandang disabilitas di kota payakumbuh pada pilkada.

\section{HASIL dan PEMBAHASAN}

\section{Faktor Internal}

Dalam faktor internal setiapdisabilitas memiliki orientasi politiknya masing masing dalam menyikapi hak politiknya.Orientasi Politik yang dimiliki oleh penyandang disabilitas mempengaruhi motivasinya dalam memutuskan dirirnya dalam bersikap pada Pilkada Kota Payakumbuh. Setiap adanya orientasi yang mempengaruhi motivasi penyandang disabilitas dalam memilih ini juga tidak terlepas dari pengetahuannya dalam tiga hal yaitu orientasi kognisi, afeksi dan konasi dalam melihat sudut pandang orientasi mereka penyandang disabilitas.

Menurut Mery salah satu disabilitas penyandang TuneNetra di salah satu SLB Kota Payakumbuh. ${ }^{18}$

"pendidikan dan pengetahuan bagi penyandang disabilitas ikut dan turut mempengaruhi pandangannya seputar demokrasi, karena ketika mereka sadar dengan dirinya sebagai penyandang disabilitas bahwa ada hak yang harus negara untuk memenuhinya, maka mereka juga akan paham akan pentingnya kepala daerah mereka nanti, kita tidak mau juga orang - orang terpilih tersebut tidak peduli dengan nasib disabilitas kedepannya, terutama di Kota payakumbuh ini banyak sekolah disabilitas, apa lagi kami sebagai disabilitas tuna netra memiliki kebutuhan khusus yang berbeda dari orang biasa, ya... kami butuh jalan yang ramah bagi kami, pokoknya fasilitas umum yang bisa kami gunakan secara mandiri tapi mudah untuk kami gunakan. Nah, itu semua berasal dari pemerintah yang berkuasa, kami harus pintar - pintar juga memilih pemimpin jika sudah paham dengan hal begini”

\footnotetext{
${ }^{15}$ Lexy J, Moleong. 1990. Metode Penelitian Kualitatif. Bandung: Remaja Rosda Karya, Hlm. 3.

${ }^{16}$ Bab III Metode Penelitian [PDF] diakses dari Web : digilib.unila.ac.id/924/10/BAB\%20III.pdf ${ }^{17} \mathrm{Ibid}$.

${ }^{18}$ Wawancara dengan Mery Zawati, Guru Disabilitas di SLB YLPB Kota Payakumbuh penyadang disabilitas Tuna Netra
} 
Dari wawancara dengan mery, seorang guru disabilitas yang juga seorang tuna netra, terlihat bahwa pengetahuan yang ada pada dalam diri disabilitas juga akan mempengaruhi keinginannya untuk ikut berpatisipasi, ketakutannya akan pemimpin yang tidak peuduli dengan nasib para penyandang disabiltias membentuk orientasi kognisi politiknya untuk ikut turut serta mengambil sikap dalam memilih, karena tingkah laku individu berhubungan erat atau ditentukan juga oleh pengetahuan dan pendidikan seseorang. ${ }^{19}$ Sementara itu munculnya Motivasi pada seoang disabilitas atas keikutsertaannya dalam Partisipasi seperti ikut Memilih juga pengaruhatsas pengetahuan yang dimiliki disabilitas karena pendidikan tadiyang sedikit banyak telah mempengaruhi pola pikir mereka sebagai disabilitas dalam menyikapi hak politik dan berdemokrasi di daerahnya, adanya kesadaran Politik terhadap perkembangan Politik di Kotanya, seperti : Perasaan mengerti dan sadar, adanya minat terhadap politik serta perhatian terhadap politik. ${ }^{20}$

Perrmasalahan lainnya kembali disampaikan lagi oleh Mery, sosialiasai sebagai edukasi politik dan demokrasi bagi kaum disabilitas nyatanya tidak semua disablitas merasakan. ${ }^{21}$ Padahal pentingnya sebuah sosiasliasi akan memunculkan sebuah kekuatan motivasi pada disabilitas. Meski tidak mendapatkan edukasi yang baik dari penyelengara, tetapi basi para penyandang disabilitas masih, mereka masih memilikikepercayaan terhadap pemerintah. Kepercayaan terhadap pemerintah ini dapat juga diartikan penilaian seseorang terhadap pemerintah apakah pemerintah dapat dipercaya dan dapat dipengaruhi. Kepercayaan ini terlihat dari keyakinan pada bawha Pemerintah melalui kegiatan itu "Pilkaada" kepentingan mereka akan tersalur atau sekurangnya diperhatikan dan sedikit banyak dapat mempengaruhi tindakan yang berwenang yang diwujudkan dalan sebuah keputusan. ${ }^{22}$

"Sejauh ini pada Pilkada kami selalu ikut dan berpatisipasi menggunakan hak pilih kami, baik itu pilgub maupun pilkada pemilihan walikota Payakumbuh, tetapi bagi saya sebagai guru disabilitas sekaligus juga disabilitas penyandang tuna netra sosialisasi yang diberikan oleh Kpud kota payakumbuh masih banyak dsabilitas yang belum terjangkau, karena kpu hanya melakan sosialisas kepada sekolah sekolah saja, padahal banyak disablitas yang tidak lagi sedang dala penddikan, dan di sekolah kami tempat kpu melakukan wawancara mereka tidak ada megundang disabltas di luar sekolah, meskipun demikian kami masih memiliki semangat dalam ikut memilih pada Pilkada. Meski banyak dari kawankawan tidak mendapati edukasi politik yang tepat sasaran."

Meski tidak maksimalnya perlakukan sistem politik kepada para penyandang disabilitas, akan tetapi mereka masih memiliki orientasi afeksi yang baik dalam melihat

\footnotetext{
${ }^{19}$ Freed J greinstein dan Nelson W Polsby. Handbook Of Political Science "Micropolitical Theory) Vol3.

${ }^{20}$ Op.cit , hal 24

${ }^{21}$ Op.cit, hal 47

${ }^{22}$ Wawancara dengan Mery, Penyandang disabilitas Tuna Netra
} 
Pilkada pada sebua sistem politik yang ditampilkan ${ }^{23}$. Pengaruh dari orientasi afeksi atas perlakuan penyelenggara tidak berpengaruh kepada beberapa disabilitas yang ada khususnya yang tergabung dalam sekolah-sekolah dan ikatan PPDI.

Sementara itu menurut David J, (Penyandang disabilitas Tuna Rungu, (wawancara dibantu oleh guru penerjemah bahasa isyarat yang bernama Melia P. N)dengan pendalaman yang sama kami lakukan dalam mengenai perhatian pihak penyelenggara seperti KPUD dalam memberikan motivasi kepada pemilih.

"saya adalah seorang penyandang disabilitas Tuna Rungu, secara fasilitas ketika memilih, saya tidak memerlukan bantuan apapun dalam memilih, namun secara informasi tentang seputar Pilkada saya sedikit kesulitan untuk mengetahui hal hal seputar politik, tetapi disekolah ini para guru ikut membantu saya untuk mengenali apa itu demokrasi, khususnya demokrasi di Kota Payakumbuh, saya juga tahu para Kandidat calon kepala daerah yang ingi dipilih. Jadi informasi yang saya dapatkan seputar demokrasi dan Pilkada Khususnya bukan dari KPUD akan tetapi tempat saya sekolah yaitu SLB ini “

Pendidikan yang ada pada dalam diri disabilitas mempengaruhi pengetahuan dalam mencari tahu informasi seputar demorkasi dan Pilkada. Selain ituMenurut Kenneth Blanchard dan Spencer Johnson ada tiga jenis atau tingkatan motivasi seseorang, yaitu: Motivasi yang didasarkan atas ketakutan (fear motivation). Dia melakukan sesuatu karena takut jika tidak maka sesuatu yang buruk akan terjadi. Motivasi karena ingin mencapai sesuatu (achievement motivation). Motivasi ini jauh lebih baik dari motivasi yang pertama, karena sudah ada tujuan di dalamnya. Seseorang mau melakukan sesuatu karena dia ingin mencapai suatu sasaran atau prestasi tertentu. Motivasi yang didorong oleh kekuatan dari dalam (inner motivation), yaitu karena didasarkan oleh misi atau tujuan hidupnya. Seseorang yang telah menemukan misi hidupnya bekerja berdasarkan nilai (values) yang diyakininya. ${ }^{24}$ Dan apa yang dikatakan disabiltias di atas adalah bagian dari mtoivasi memilih yang hadir karena dorongan kekuatan memiliki misi dalam hidupnya, atau inginkan adanya perubahan pada Kaum disabilitas kedepannya.

Seorang disabilitas lainnya dengan umur 70 tahun bernama kamardi yang sudah sering terlibat ikut dalam Pilkada juga menyampaikan hal yang sama tentang pandangannya terhadap demokrasi dan Pilkada, dan bagaimana harapannya terhadap demokrasi Kota payakumbuh kedepannya.

"saya sudah banyak ikut dalam pemilu, apopun itu, sayakan sudah berumur 70 tahun, dari bupati sampai walikota, sekarang saya merasakan pemilu itu. Saya ikut pemilu bukan karena imng-imingan uang, hanya karena saya sadar akan pentingnya itu. Tapi banyak juga teman-teman saya yang tidak ikut, padahal mereka manusia normal tidak seperti saya yang banyak kurangnya ini.Kaki

\footnotetext{
${ }^{23}$ Op.cit Hal 21

${ }^{24}$ Op.cit hal 24
} 
patah ini tidak jadi alasan saya tidak ikut memilih. Sekarang saya di undang KPU D Kota Payakumbuh datang ke kantor mereka, untuk menjadi percontohan disabiltas yang peduli akan Pemilu, tapi bukan berarti saya ikut memilih karena ajakan KPU karena cuman saya sadar sendiri, ini penting, demi masa depan kehidupan disabilitas memahami Politik di Kota ini harus dilakukan , karena masa depan kita akan ada pada mereka yang terpilih untuk lima tahun kedepan."

Dari identifikasi tersebut, pernyataan dari para penyandang disabilitas terlihat bahwa mereka kesulitan dalam mendapatkan Informasi tentang Pemilihan Umum kepala daerah Kota Payakumbuh, hal tersebut tentu mempengaruhi kognisi orientasi dalam artian pengetahuan mereka dalam memahami sebuah Pemilu akan merubah sudut pandang mereka terhadap Pilkada Kota Payakumbuh. Sebab pentingnya sebuah pengetahuan pada diri disabilitas tidak hanya menghasilkan sebuah kepekaan tentang demokrasi namun juga kualitas demokrasi yang dihasilkan oleh pilihan para disabilitas itu sendiri.

Dengan adanya pendidikan, pengetahuan dan harapan, para penyandang disabiltias yang memahami seluk - beluk demokasi secara sederhana akan memiliki rasa tanggung jawab tentunya pada pemilihan umum sebagai pemilih, akan tetapi bagi mereka yang memiliki pengetahuan tadi namun kurangnya kepercayaan kepada sistem seperti KPUD yang seolah tidak memahami keadaan mereka juga, pada akhirnya berdampak kepada orientasi mereka dalam Pemilihan Umum, karena ada pemikiran atau motivasi mereka nantinya, yaitu orientasi dalam sebuah keputusan, sehingga nantinya akan memberikan suntikan motivasi dalam ikue memilih tidaknya mereka dalam Pemilu.

Menurut Rika Septiawati, seorang siswa disabilitas Tuna Netra yang ada di SLB Peduli Anak Bangsa menjelaskan tentang motivasi dan orientasinya dalam memilih. ${ }^{25}$

"Pada Pemilu kemarin saya menggunakan Hak pilih saya sebagai Pemilih, meskipun beberapa kawan saya sesama disabilitas ada yang tidak menggunakan hak pilihnya, saya tetap menggunakan hak pilih saya, saya mencoblos pada Pilkada kemarin itu. Meskipun saya tidak bisa melihat, namun saya cukup banyak mendengar dan diberitahu memlaui cerita oleh kawan dan sanak family tentang kandidat walikota yang ada. Di media sosial saya juga berteman dengan orang - orang yang memberitahu saya tentang pilkada, melalui aplikasi khusus yang bisa membaca kata - kata di media sosial yang menjadi suara, di sana saya terbantu untuk menambah wawasan saya, salah satunya tentang pilkada tadi, jadi saya juga tidak bisa dibodohi nantinya ketika Pemilihan berlangsung. Maka mudah bagi saya ketika memilih menentukan hak pilih saya, saya juga diberi kemudahan dengan fasilitas kertas surat suara yang bisa saya baca. Saya memilh karena sadar ingin adanya perubahan pada Kota Payakumbuh, saya juga

\footnotetext{
${ }^{25}$ Wawancara rika septiawati. Disabilitas penyandang Tuna Netra.
} 
membaca janji janji kemapanye yang diberikan oleh para calon, sehingga saya paham nantinya arah kebijakan seperti apa yang akan saya dapati nantinya."

Dari pernyataan Rika di atas, terlihat bahwa orientasi Rika dalam memilih adalah keinginananya tentang perubahan Kota Payakumbuhsama seperti yang disampaikan oleh Mery di atas. Adanya informasi yang Rika dapatkan, membuat sebuah orientasi Politik dalam dirinya, sehingga muncul sebuah motivasi yang membuat Rika ingin terlibat dalam Pilkada Kota Payakumbuh.Orientasi yang ada membentuk sebuah ideologi, baik pada seseorang atau lembaga.Seperti lembaga disabilitas PPDI, menurut Icun Sulhadi tentang Orientasi Politik PPDI.

"Sebagai disabilitas tunanetra dan ketua PPDI Sumatera Barat, PPDI adalah lembaga yang mewadahi kawan-kawan disabilitas dalam hal apapun. Kami sudah seperti satu keluarga di dalamnya.Dan untuk hal seperti Pilkada kami yang terhimpun dalam komunitas ini memang menyerukan untuk menggunakan hak pilih kami dalam Pemilu apapun itu, walaupun itu Pilkades sekalipun. Karena PPDI menyadari pentingnya sebuah demokrasi, kami sering juga berdiskusi antara sesama tentang para kandidat yang mencalonkan dirinya, bahkan kami juga di undang untuk hadir dalam kampanye mereka.Tapi kami tetap berada dalam zona netral.Tidak memihak kepada siapapun. Untuk pilkada kota payakumbuh teman saya kamarudin juga sudah diminta untuk memberikan arahan untuk ikut memilih pada Pilkada Kota Payakumbuh"

Motivasi Politik adalah sesuatu yang mendorong seorang Individu Politik untuk ikut terlibat dalam sistem politik yang berlangsung, sehingga mereka ada keinginan keinginan dari orientasi dapat mereka harapkan kedepannya.Dua hal dari orientasi dan motivasi adalah dua hal yang berkaitan dalam mendorong keputusan Individu setiap disabilitas dalam memilih ataupun tidak memilih pada Pilkada Kota Payakumbuh.

Sementara itu Menurut David J sebagai disabilitas Tuna Rungu, menurutnya tentang bagaimana dirinya memutuskan dalam memilih atau tidaknya pada Pilkada Kota Payakumbuh Tahun 2017. ${ }^{26}$

"bagi saya keputusan untuk ikut memilih adalah sikap untuk ikut serta berdemokrasi, meskipun saya tidak menerima sebuah sosialisasi dari KPUD namun saya yang memiliki hak pilih tidak hanya mencari tahu tentang Pilkada dengan mengharapkan informasi dari KPUD, malah seperti yang saya sampaikan tadi, di sekolah saya ini para guru memberikan informasi seputar Pilkada dan pentingnya bagi saya dan kawan kawan lain untuk menggunakan hak pilihnya sebagai penyandang disabilitas".

Adanya kesadaran dari David adalah bentuk motivasi politik terhadap perkembangan demokrasi yang ada di Kota Payakumbuh, karena ini adalah bentuk motivasi intrinsik, sama halnya dengan orientasi yang berasa dari dua hal. motivasi

\footnotetext{
${ }^{26}$ Wawancara David, Disabilitas Penyandang Tuna Rungu.
} 
politik juga berasal dari dua hal yaitu intrinsi dan ekstrinsik. Apa yang dilakukan oleh David adalah sebuah motivasi intrinsik atas perasaan kesadaran, minat dan perhatiannya ingin mengetahui suatu hal dari demokrasi. ${ }^{27}$

Lain halnya dengan Mery zawati yang tidak menggunakan hak pilihnya pada Pilkada Kota Payakumbuh, menurutnya, Karena tidak tepatnya sasaran sosialisasi yang dilakukan oleh KPUD. ${ }^{28}$

"saya tidak ikut memilih pada Pilkada Kota payakumbuh, meskipun sekolah tempat saya mengajar dan saya juga sebagai disabilitas tune netra, akan tetapi saya adalah orang yang memiliki KTP Lima Puluh Kota, artinya tidak ada hak pilih saya pada Pilkada Kota Payakumbuh, tetapi pada Pilgub dahulu 2015 saya ikut memilih di sini karena cakupannya provinsi dan lima puluh kota dan payakumbuh masih satu provinsikan. Tidak hanya itu kebanyakan siswa di sini juga tidak ber KTP di Kota Payakumbuh, bisa dikatakan sosialisasi yang dilakukan oleh KPUD Kota Payakumbuh adalah hal yang tidak tepat sasaran, bisa dikatakan itu juga semacam formalitas semata bahwa mereka telah melakukan kewajiban sebagai penyelenggara untuk menyentuh semua lapisan termasuk disabilitas, padahal harusnya mereka mencari disabilitas- disabilitas yang terdata untuk di undang lalu dikumpulkan untuk diberikan sosialisasi seputar Pilkada Kota Payakumbuh"

Dari tiga orang informan di atas, maka dapat dijelaskan bahaw faktor - faktor internal orientasi dan motivasi intrinsik adalah hal yang mempengaruhi mereka kurang lebih dengan banyak kesamaan, meski persoalan Mery lebih kepada kategorinya sebagai orang yang bukan memiliki hak pilih namun mendapatkan sosialisasi Politik dari KPUD Kota Payakumbuh. Sementara Rika dan david adalah dua orang yang secara pengetahuah sedikit banyak telah memahami sebuah negara demokrasi, terkhusus demokrasi yang ada di Kota Payakumbuh. Sehingga orientasidari dua orang tersebut terbentuk dengan sendirinya menjadi sebuah motivasi Politik.Dan Motivasi intrinsiksebuah pemahaman tetang sistem politik yang ada dan juga sebuah keinginan perubahan yang untuk daerahnya. Sehingga melahirkan motivasi atas dasar seperti rasa takut akan terpilihnya orang yang salah nantinya, atau motivasi ingin menciptakan perubahan melalui sistem Pemilu itu sendiri. Dengan adanya motivasi instrinsikdan orientasi politik, membuat seseorang dalam Pilkada Kota Payakumbuh memiliki keinginan dan muatan masing-masing untuk sebuah alasan pada setiap keputusan politiknya pada Pilkada. Seperti menanamkan suatu harapan perubahan atau pembaharuan pada Pilkada tersebut.Seperti kata Icun Suhaldi yang merupakan disabilitas Tuna netra sekaligus Ketua PPDI Kota Padang. Ketika peneliti temui di sekolah tempat beliau mengajar ${ }^{29}$

\footnotetext{
27، 'Sobirin Malian", Op.cit hal 23

${ }^{28}$ Wawancara mery zawati, Disabilitas Penyandang Tuna Netra

${ }^{29}$ Wawancara Icun Suhadi. Ketua PPDI Kota Padang dan Guru dengan Disabilitas Tuna Netra
} 
"Disabilitas memiliki harapan - harapan pada setiap Pemilihan Umum, mereka sebagai orang berkebutuhan khusus tentunya sangat berharap banyak pada setiap orang yang menjadi kepala daerah di kotanya masing - masing, karena nantinya pada mereka kita - kita ini akan menuntut untuk dipenuhi hak kam sebagai disabilitas di kota tersebut. Jadi jelas orientasi kami yaitu sebuah perubahan, kebijakan yang akan diambil nantinya oleh pemerintahan berharap dari kami sangat memperdulikan nasib kawan - kawan disabilitas di daerah. Biasanya para calon - calon itu juga ada yang menemui, sehingga nanti ada janji - janji yang nantinya kami tuntut ketika mereka terpilih sebagai kepala pemerintah atau wakil kamilah di sebuah pemerintahan.“

Hal ini juga dibenarkan oleh disabilitas Tuna Daksa asal Kota Payakumbuh yang juga sebagai perwakilan PPDI di Kota Payakumbuh bapak Kamardi yang merupakan disabilitas Tuna daksa dengan lumpuh kaki total. Menurut bapak kamardi yang kebetulan peneliti temui di Kantor KPUD Kota Payakumbuh tentang orientasi disabilitas di Kota Payakumbuh Dalam memilih adalah. ${ }^{30}$

"Kebanyakan dari kami para disabilitas, ikut memilih tenteu awalnya karena kesadaran tentang pentingnya itu dilakukan, saya sebagai orang tua disabilitas, dari dulu selalu ikut, saya banyak menemui para calon - calon yang ada, bahkan di sana menyampaikan pesan - pesan kawan disabilitas agar nanti ketika mereka terpilih dapat memperhatikan nasib kami. Kebanyakan orientasi disabilitas dalam memilih ya..karena ingin adanya perubahan terhadap nasib kami para disabilitas, ya...semacam lihatlah kami ini. Perhatikan, bahwa kami ada sebagai kaum yang terpinggurkan, kadang banyak juga masyarakat yang belum paham dengan kami, jadi ikut dalam memilih itu orinetasinya ya karena ingin dimengertilah nantinya. Biar ketika mereka pas pemilihan mengenal kami, nanti pas duduk juga masih ingat kami, jadi nanti kami punya kenalan dipemerintah untuk bisa kami sampaikan masukan untuk melihat kami”

Adanya orientasi politik dan motivasi instrinsik adalah suatu kesatuan yang membentuk kognisi atau padangan sikap para disabilitas dalam menentukan sikap politiknya. Dengan adanya kognisi mereka atau pengetahuan tentang pemilu maka akan adanya pemahaman tadi yang mendorong mereka memiliki nilai - nilai dalam diri (internal) untuk memutuskan hak pilih yang mereka punya.

Dengan adanya Motivasi Politik dan Orientasi Politik para disabilitas tadi, hal itu yangmenjadi dasar mereka ikut berpatisipasi atau tidak, sederhananya memilih atau tidak. Pada akhrinyaakan menghasilkan sebuah Kualiatas Partisipasi di kalangan disabilitas, dan ini adalah umpan balik dari koginisi tadi sehingga menghasilkan sebuah tindakan dan tindakan menghasilkan sebuah hasil partisipasi tadi "memilih atau tidak memilih dalam Pilkada.

\footnotetext{
${ }^{30}$ Wawancara, Kamardi, ketua PPDI Kota Payakumbuh dan disabilitas tuna daksa n dengkelumpuhan kaki total.
} 
Menurut Komisioner KPUD Ade Juniarti Marlia tentang partisipasi disabilitas. ${ }^{31}$

"Kualitas Partisipasi pada Pilkada Kota Payakumbuh tahun 2017 cukup baik, tetapi ya harus kami akui bahwa dikalangan disabilitas itu memang agak rendah ya, kami sebenarnya sudah berupaya dengan melakukan sosialisasi kepada mereka agar mereka memahami tentang Pilkada ini dan pentingnya satu suara mereka untuk demokrasi Kota Payakumbuh, ya itu kembali lagi kepada mereka ya mau ikut atau tidaknya dalam memilih, kadangkan persoalannya ya karena mereka mungkin ada kesibukan lain ketika hari pemiliha tadi, jadi tidak bisa ke TPS, kalau kami sudah berupaya sebaik mungkin untuk menggaet semua lapisan dan kalangan untuk ikut berpatisipasi, termasuk para kawan - kawan difabel atau disabilitas".

Dari identifikasi di atas jika disinkronkan dengan penjelasan wawancara bersama para disabilitas yang menyatakan bahwa sosialisasi atau edukasi seputar Pilkada dilalkukan tidak tepat sasaran, maka di sini saya temukan adanya sebuah penampikan penyelenggara dalam hal sosiaalisasi yang dilakukan khusus untuk disabilitas.Maka bisa di katakan bahwa faktor yang membuat rendahnya Kualitas Partisipasi Di Kota Payakumbuh ada kemungkinan karena kurang efektifnya sosialisasi yang dilakukan oleh pihak penyelenggara. Jika menelaah tentang kualitas maka kaitannya dengan faktor ektsternal wajib rasanya untuk peneliti identifikasi.

\section{Faktor Eksternal}

Faktor eksternal adalah sistem yang mengatur para disabilitas dalam menjalani kehidupannya, termasuk undang-undang No. 8 tentang disabilitas dan lebih khususnya arah kebijakan penyelenggara dalam memaknai kehadiran mereka dalam pemilu. Sehigga nanti akan turut menjadi hasil atas tindakan mereka dalam memutuskan pilihannya dalam menggunakan hak pilihnya pada Pemilu. Maka dari itu peneliti mencoba menggali tentang keberadaan disabilitas tersebut kepada salah satu komisoener KPUD Kota Payakumbuh Bpk Yuzalmon.Peneliti pertama mencoba mempertanyakan bagaimana sosialisasi yang diberikan kepada para disabilitas sebagai hak mereka mendapati edukasi seputar demokrasi khususnya Pilkada tersebut. Karena rendahnya angkapartisipasi politik peenyandang disabilitas yang ada selain berasal dari faktor internal juga dipengaruhi oleh faktor eksternal. Karena sebuah tindakan yang ditampilkan seseorang merupakan dari dua hal utama, yaitu karakterstik pribadi dan lingkungan tempat orang itu berada. ${ }^{32}$ Lingkungan yang dimaksud disini adala sistem politik yang mengatur hak-hak para penyandang disabilitas

Menurut Yuzalmon salah satu Komisioner KPUD Kota Payakumbuh yang membidangi Hubungan Masyarakat, menjelaskan tentang edukasi politik dan sosialisasi

\footnotetext{
${ }^{31}$ Wawancara dengan Ade Komaria. Komisioner KPUD Kota Payakumbuh divisi Hukum

${ }^{32}$ Op.cit hal 17
} 
Pilkada terhadap disabilitas yang sudah mereka lakukan sebagai usaha pemenuhan hakhak para penyandang disabilitas ${ }^{33}$

"Sosialisasi dan edukasi politik kepada disabiltas adalah inisiatif kami saja sebagai penyelenggara, lewat segala media, bahkan juga radio. Beruntung kami sudah melakukan sosialisasi kepada disabilitas, karena kami memiliki kepedulian terhadap mereka, karena mereka juga pemilih dan memiliki hak untuk memilih dan dipilih jika mereka itu mencalonkan diri kalau hal dipilih ini ya.tapi dalam aturan tak ada kewajiban harus kepada mereka, ini saya katakan inisiasitif kami saja untuk agendakan sosialisasikan kepada mereka, karena kami memahami kondisi disabilitas memang membutuhkan penanganan yang khusus, tapi bukan berarti di istimewakan, itu gak boleh juga, kadang mereka malah menolak untuk di istimewakan dan malah memilih untuk diperlakukan secara normal manusia kebanyakan".

Dari pernyataan di atas, agaknya penyelenggara kurang berkaca pada UndangUndang No. 8 tentang penyandang disabilitas, sementara di sana adalah segala hak para disabilitas termasuk tentang hak untuk ikut berpatisipasi dan berpolitik juga di atur dalam undang-undang tersebut, jika penyelenggara sadar akan pemenuhan Hak maka harusnya disabilitas mendapatkan perhatian lebih tanpa harus memandang sisi lain seperti inisiatif. Sementara itu menurut kepala dinas sosial dan tenaga kerja Kota Payakumbuh bapak Idris tentang kurangnya kesiapan penyelenggara ini, belliau menjelaskan $^{34}$.

"Seharusnya hak disabilitas dalam pemilu harus dikhususkan seperti mereka sendiri yang memang memiliki keterbatasankan, seperti fasilitas pendukung dan aksesbilitas. Ini merupakan kewajiban penyelenggara dalam memaknai keberadan mereka yang diatur undang-undang no 8 tentang disabilitas. Dengan rendahnya angka partisipasi disabilitas seperti yang andre sampaikan tadi kepada bapak, sebenarnya kami cukup kecewa, karena sekolah-sekolah luar biasa yang ada harusnya berdampak pada tingkat partisipasi mereka yang baik, sebab saya percaya mereka berpendidikan pasti paham tentang pentingnya ini. jadi jika disabilitas itu sudah berpendidikan mereka menurut saya akan paham tentang pentingnya pemilu ini. Saya juga sering menyuruh mereka untuk aktif terlibat dalam berbagai hal termasuk pemilu, dan untuk acara yang di adakan oleh KPUD Kota Payakumbuh di YLPB khusus Tuna Netra itu juga kami kurang tahu kenapa tempat tersebut saja yang dijadikan sosialisasi, harusnya juga ada kordinasi bersama kami biar tepat sasaran, karena kami tahu dan memiliki data tetang disabilitas yang mungkin lebih baik dari KPUD Kota Payakumbuh. Karena kami telah mendata itu sebelum Pemilu sementara setahu saya pendataan

\footnotetext{
${ }^{33}$ Wawancara dengan Bpk Yuzalmon, Komisioner KPUD Kota Payakumbuh divisi Humas

${ }^{34}$ Wawancara dengan Bpk Idris A.Ks, M,Si Kepala Dinas Sosial dan Ketenaga kerjaan Kota Payakumbuh.
} 
KPUD Kota Payakumbuh itu dilaksanakan sebelum data itu dapat.Jadi kurang tepat rasanya mereka memberikan sosialisasi di tempat tersebut."

Dari pernyataan kepala dinas tersebut memang terlihat kurangnya sinergi KPUD Kota Payakumbuh dengan mitra lembaga lainnya yang memahami kondisi para disabilitas di Kota Payakumbuh. Selanjutnya peneliti menemui juga salah satu caleg dari Partai Kader (Partai PKS) Adek Fauzan di rumahnya. Dari perbincangan tersebut hal yang disampaikan oleh kepala Dinas Sosial dan Ketenaga kerjaan Kota Payakumbuh kurang lebih hampir sama. ${ }^{35}$

"saya tidak tahu jika partisipasi para disabilitas rendah di kota ini, tapi menurut saya jika benar kata andre dari data yang dibawa, menurut saya ini adalah tanggung jawab KPU sendiri untuk menjelaskan hal ini. Padahal dana penyelenggaraan ini menurut saya sangat besar, harusnya mereka dapat menyentuh semua kalangan untuk digiring ikut melek akan politik seperti pilkada. Disabilitas itukan butuh penanganan khusus, harusnya juga khusus yang diberikan. Orang buta butuh pendampingan, orang bisu juga, dan lain lain. Saya juga tidak tahu jika sosialiasi itu dilakukan di slb tersebut, menurut saya SLB itu berada diperbatasan kota, isinya mungkin beragam tidak semua orang kota, mungkin ada kabupaten. Sementara inikan Pilkada, tidak tepat rasanya jika sosialisasi itu di sana. Harusnya ya dikumpulkan mereka dengan data yang sebenarnya. Dan kalau bisa undang juga kami untuk mengenalkan gagasan kami untuk mereka kedepannya jika duduk. Ini juga potensi kan bagi saya meraup suara. Hehehe. Dengan angka dibawah 50\% tadi sangat disayangkan ya. Sementara untuk para kandidat calon bupati bersama partai memang tidak ada yan fokus juga terhadap suara disabilitas, kami mencari suara dari pertemuan masyarakat yang golongannya semua sama, beragam tidak ada fokus disabilitas, tapi ada disabilitas yang ikut acara-acara kami ada".

Dari pernyataan adek fauzan tersebut terlihat sangat menyayangkan bagaimana penyelenggara dalam melakukan sosialisasi yang kurang tepat sasaran, padahal tidak hanya KPUD yang harusnya turun tangan dalam menggaet aspirasi disabilitas dalam Pilkada, padahal Motivasi ekstrinsik berasal dari sistem politk yang ada termasuk Partai Politik dalam mempengaruhi disabilitas. Motivasi ekstrnsik berasa dari perangsang luar, terdiri dari peer dan simbol pergerakan.Peer group adalah lingkungan sosial dari invididu dimana proses sosialisasi dan tranformasi dapat berjalan, seperi kekuatan identitas partai dan tampilan dari kandidat calon Kepala daerah yang ada. ${ }^{36}$ Lalu peneliti juga bertanya tentang target KPUD Kota Payakumbuh dalam angka partisipasi disabilitas di Pilkada. Menurut yuzalmon ${ }^{37}$

\footnotetext{
${ }^{35}$ Wawancara dengan Adek fauzan, Politisi dan Caleg Kota Payakumbuh dari Partai Keadilan Sejahtera

${ }^{36}$ Sobirin malian,Op.cit hal 23

${ }^{37}$ Wawancara dengan yuzalmon, Op.cit.cit. Hal 56.
} 
"kami kpu tidak memiliki target yang kami bebankan pada untuk kami penyelenggara, tapi saya pribadi memiliki harapan kalau mereka itu mampu lebih di angka 70\% angka partisipasinya. Karna kamikan sudah sosialisasi untuk mereka, maka saya pun optimis angka itu bakalan bisa tercapai.Sekali lagi, KPUD tidak ada target, hanya pribadi bapak saja. Usaha sudah maksimal, hasil berkata lain kita mau apa, tidak mungkin pula kita memaksa-maksa mereka untuk menggunakan hak pilih. Sementara untuk fasilita dan aksesbilitas kami sudah berikan rasanya."

Dari pernyataan Yuzalmon, peneiliti mengidentifikasi bahwa tidak ada target yang jelas dari KPUD untuk mendongkrak angka partisipasi disabilitas, dan juga kurangnya kordinasi penyelenggara untuk memahami kondisi disabilitas dalam Pilkada, seperti dengan dinas sosial, dan tidak memahami pentingnya undang-undang No 8 Tentang Penyandang Disabilitas yang sudah negara atur keberadaanya.

Maka, berdasarkan hasil penelitian yang dilakukan, peneliti berkesimpulan bawhasanya Partisipasi Penyandang dsiabilitas di Kota Payakumbuh tidak berjalan maksimal, Hal ini disebabkan oleh antaranya

a. Faktor internal

Disabilitas Individu -Individu para penyandang disabilitas, Karena beberapa dari penyandang disabilitas masih belum bisa memaknai pentingnya sebuah pemilihan umum, dan kurangnya edukasi seputar demokrasi yang didapatkan dari penyelenggara.

\section{b. Faktor eksternal}

KPUD Kota Payakumbuh kurang memahami kondisi disabiltias, seperti jumlah dan keadaanya. Sehingga sosialisasi yang diharapkan dapat membantu meningkatkan angka partisipasi para penyandang disabilitas di Kota Payakumbuh tidak berjalan dengan baik. Sementara itu lembaga dinas terkait seperti dinas sosial juga tidak menyadari sosialisasi yang diberikan tidak tepat sasaran, beggitu juga dengan organisasi khusus para penyandang disabilitas seperti PPDI yang menyadari sosialisasi tersebut terkesan setengah hati.

\section{KESIMPULAN}

Berdasarkan hasil penelitian yang dilakukan tentang bagaimana Partisipasi Penyandang Disabilitas Pada Pilkada Kota Payakumbuh Tahun 2017, dapat disimpulkan bahwa, pada pelaksanaanya yang dilakukan oleh KPUD Kota Payakumbuh dapat dikatakan hasilnya kurang maksimal dalam meningkatkan partisipasi penyandang disabilitas. Hal ini disebabkan oleh dua hal, yakni karena faktor Eksteral dan Internal. Faktor internal yaitu bagaimana kondisi diri disabilitas dalam memahami Pilkada Kota Payakumbuh. Pada hal ini disabilitas yang tergabung dalam Persatuan Penyandang Disabilitas Indonesia (PDDI) telah memiliki pandangan yang baik sebenarnya, seperti 
kognisi atau pengetahuan penyandang disabiltas yang ada telah memberikan orientasi memilih dan motivasi memilih yang baik untuk ikut memilih pada Pilkada Kota Payakumbuh, akan tetapifaktor eksternal tidak mendukung hal ini untuk merangkul orang-orang selain yang ada di PPDI, karena pada faktor Eksternal dimana KPUD sebagai penyelenggra tidak memiliki keinginan untuk menunjang angka partsipasi disabilitas dalam pilkada Kota Payakumbuh, sehigga mereka merasa tidak memiliki beban dalam upaya meningkatkan angka partisipasi disabilitas.Hal ini dikarenakan juga KPUD Kota Payakumbuh kurang memahmi kondisi penyandang disabilitas yang ada di Kota Payakumbuh, sehingga tidak ada angka pasti dari sebaran angka penyandang disabilitas yang dapat menjadi fokus mereka untuk diberikan sosialisasi khusus terhadap Penyandang Disabilitas. Pada akhirnya ketidaktepatan sasaran penyelenggara dalam memberikan sosialisasi terhadap penyandang disabilitas mempengaruhi rendahnya angka partisipasi tersebut. Karena tidak tepatnya sosialisasi yang diberikan oleh faktor eksternal "KPUD" maka kurangnya pemahaman dan pengetahuan disabilitas sendiri dalam memaknai pentingnya sebuah partisipasi mereka dalam Pilkada Kota Payakumbuh juga menjadi imbas dari disabilitas yang tida tergabung dalam sekolah disabilitas dan PPDI, maka dari $42 \%$ yang memilih maka 58\% yang tidak memilih adalah mereka yang tidak kurang memahami pengetahuan tentang kepemiluaan dan pentingnya sebuah demokrasi bagi disabilitas sendiri. Tambahannya adalah tidak adanya kordinasi lembaga terkait seperti dinas sosial, PPDI dan KPUD dalam menjangkau paritispasi disabilitas pada Pilkada Kota Payakumbuh, sehingga sinergisitas yang dibangun pada lembaga-lemabaga tidak berjalan, sementara upaya memahami hak disabilitas pasca adanya Undang-Undang No.8 tentang disabilitas harusnya telah menjadi kewajiban bersama antra lembaga dalam memenuhi hak penyandang disabilitas secaramaksimal. 


\section{DAFTAR PUSTAKA}

\section{Buku :}

Arikunto, Suharsimi. 2005. Manajemen Penelitian ( edisi Revisi ). DKIJakarta: Rineke Cipta.

Budihardjo Miriam, 1982. Dasar-dasar Ilmu Politik "Partisipasi dan partai Politik, Jakarta: PT.Gramedia.

Bungin, Burhan. 2003. Analisa Data Penelitian Kualitatif. Jakarta: PT.RajaGrafindo Persada.

Christopher Llyod, 1986, Teori sosial dan Praktek Politik, Jakarta: PT. Rajawali

Damsuar. 2010. Buku Pengantar Sosiologi Politik “partisipasi Politik”. Jakarta: Kencana Prenada Grup .

Elly, M setiadi dan Umsan Kolip. 2013. Pengantar Sosiologi Politik, Jakarta: Kencana prenada grup

Fred J. Greenstein dan Nelson W.1978, Polsby handbook of political science volume III

Lexy J. Moleong. 1990. Metode Penelitian Kualitatif. Bandung : Remaja Rosda Karya.

Sobirin Malian, 2016, Menakar Loyalitas dan Volatilitas Pemilih Pada Pemilu 2004, Lampung, UNISIA, hal 81.

\section{INTERNE DAN E-JURNAL}

A. Hartina, 2014, pada e journal dengan Judul "Partisipasi Politik Pemilih Dalam Pemilihan Umum Kepala Daerah Provinsi Kalimantan Timur tahun 2013 di Desa Saliki Kecamatan muara badak kabupaten kutai, hal 4 diakses pada 7 maret 2018

Bab III Metode Penelitian, digilib.unila.ac.id/924/10/BAB\%20III.pdf [PDF] diakses dari pada tanggal 22 februari 2018.

Steve Martin Cohen dan Robert E. Kapsis.Oxford Jounals, Oxford University Pers. Participation Of Blacks, Puerto Ricans, and white in voluntary Associations: A test Of current Theories* Oxford Journals di akses 31 Juli 2018

Kemenkumham, 2011, Konvensi Hak-Hak Penyandang Disablitas (Convetion On The rights Of Persons With Disabilities) https://jabar.kemenkumham.go.id/attachments/article/1493/konvensi\%20 hakhak\%20penyandang\%20disabilitas.PDF di akses pada 1 maret 2018. 
Mahkamah Konstitusi, Tentang Perubahan Undang-undang No 1 tahun 2015 menjadi UU No. $\quad 10$ tahun 2016.http://www.mahkamahkonstitusi.go.id/public/content/jdih/UU _Nomor_10_Tahun_2016.pdf diakses pada 20 Februari 2018

M. Luthfi Munzir, Rumah Pintar Pemilu, 1(1). http://kpud-medankota.go.id/rumahpintar-pemilu/?upm_export $=p d f d i$ akses pada 1 maret 2018

Nidia Zuraya, KPU Berkomitmen Terapkan Pemilu Ramah Disabilitas, Republica.co.id diakses pada 18 agustus 2017http://nasional.republika.co.id/berita/nasional/umum/17/08/18/ouw0lmkpu-

Nissa Nurul Fathia "Partisipas Politik Penyandang Disabilitas Dalam Pemilihan Kepala Daerah Kota Bandar Lampung Tahun 2015' fakultas ilmu sosial dan ilmu politik universitas Lampung, Bandar Lampung. http://digilib.unila.ac.id/22840/3/SKRIPSI\%20TANPA\%20BAB\%20PEMBAHAS $A N$.pdf di akses pada 14/03/2018 pada pukul 14.31

Republik Indonesia ,Undang-undang No. 8 tahun 2016. http://www.kemendagri.go.id/media/documents/2016/05/11/u/u/uu_nomor_8_ta hun_2016.pdf diakses pada 1 Maret 2018

Sandra Febriyani Nur R. (14010113120056),'Partisipasi Politik Penyandang Disabilitas di Kota Semarang pada Pemilihan Walikota dan Wakil Walikota Semarang 2015', Jurusan Ilmu Pemerintahan, fisip, Universitas Diponegoro.https://media.neliti.com/media/publications/105199-ID-partisipasipolitik-penyandang-disabilit.pdfdi akses pada 14/03/2018 pada pukul 14.17 